Marquette University

e-Publications@Marquette

Theology Faculty Research and Publications

Theology, Department of

$8-21-2017$

\title{
The Shifting Ecumenical Landscape at the 2017 Reformation Centenary
}

Susan K. Wood

Marquette University, susan.wood@marquette.edu

Accepted version. Theological Studies, Vol. 78, No. 3 (August 21, 2017): 573-595. DOI. (C) 2017

Theological Studies, Inc. Used with permission. 


\title{
Marquette University
}

\section{e-Publications@Marquette}

\section{Theology Faculty Research and Publications/College of Arts and Sciences}

This paper is NOT THE PUBLISHED VERSION; but the author's final, peer-reviewed manuscript. The

published version may be accessed by following the link in th citation below.

Theological Studies, Vol. 78, No. 3 (September 1, 2017): 573-595. DOI. This article is (C) SAGE

Publications and permission has been granted for this version to appear in e-Publications@Marquette. SAGE Publications does not grant permission for this article to be further copied/distributed or hosted elsewhere without the express permission from SAGE Publications.

\section{The Shifting Ecumenical Landscape at the 2017 Reformation Centenary}

\author{
Susan K. Wood \\ Department of Theology, Marquette University, Milwaukee, WI
}

\section{Abstract}

The 2017 Reformation Centenary is the first commemoration to take place during the ecumenical age and marks fifty years of Lutheran-Roman Catholic dialogue. The current ecumenical landscape is a tale of two cities, one of ecclesial fragmentation that exists simultaneously with new relationships of communion and ecumenical progress. The way forward requires the discernment of deeper commonalities among ecclesial tradition, a correlation of doctrines, a "pastoral ecumenism," and a hierarchy of virtues in addition to a hierarchy of truths.

\section{Keywords}

church unity, ecumenism, Lutheran-Roman Catholic dialogue, Reformation, traditions

Each centenary commemoration of the Reformation occurs within a specific historical context. $\stackrel{1}{ }$ This is the first commemoration to take place during the ecumenical age and, coincidentally, it marks fifty years of LutheranRoman Catholic dialogue. Paradoxically, this centenary occurs at a time of growing ecclesial estrangement and fragmentation along with significant breakthroughs in ecumenical consensus and methodology. The ecumenical landscape in 2017 constitutes a "tale of two cities," a city of ecumenical progress and a city of ecumenical fragmentation. At this ecumenical moment when the Catholic Church has committed itself to the work for 
Christian unity and when many Lutheran churches have entered into relationships of full communion with other churches, this remarkable growth toward communion exists alongside new ecclesial fissures. $\stackrel{2}{\text { As many }}$ of the doctrinal issues at the epicenter of the Reformation are resolved or are well on their way to resolution, new divisions arise, and full, visible unity seems to be an asymptotic goal, forever out of reach.

Describing an ecumenical landscape is tantamount to a taking a bird's-eye view of a panoramic slice of time, in this instance, a Reformation anniversary. For those involved in ecumenical work, the landscape is familiar. For others, it documents the successes, tensions, and challenges that lie ahead for the next centenary.

\section{A Tale of Ecumenical Progress}

The ecumenical landscape in 2017 compared with previous commemorations includes a number of notable successes and opportunities: (1) the active participation of the Roman Catholic Church in the ecumenical movement; (2) the challenge of ecumenical reception of the results of dialogue; (3) new ecumenical methodologies that have emerged through the maturation of the process of dialogue over the past fifty years. Concurrent with these ecumenical advances, internal tension and conflict within ecclesial communities result in denominational fragmentation that often exists simultaneously with efforts to grow in communion with external ecumenical partners. The ecumenical landscape is consequently complex-a landscape of hope and progress, and of seemingly entrenched divisions.

\section{Ecumenical Engagement: A Commitment and Goal of Vatican II}

Although ecumenical commitments may still too often be considered to be at the periphery of church life, the Second Vatican Council constituted a great seismic shift in the ecumenical landscape for Catholics and marked the formal entrance of the Catholic Church into the ecumenical movement. - The Catholic attitude toward ecumenism up to that time had been most explicitly articulated by Pius XI, who wrote in his letter Mortalium Animos (1928) that "it is clear why this Apostolic See has never allowed its subjects to take part in the assemblies of non-Catholics: for the union of Christians can only be promoted by promoting the return to the one true Church of Christ of those who are separated from it, for in the past they have unhappily left it." 4 Such a statement reflects a "return ecumenism," which really is not ecumenism at all. Twenty years later in 1949, Pius XII authorized the participation of Catholics in ecumenical meetings with other Christians, which provided opportunities for growth in mutual knowledge and trust as well as the discovery of how much Christians from various traditions share in common.

For both John XXIII and Paul VI, the ecumenical agenda was intrinsic to the council. In his announcement of the council at the close of the Week of Prayer for Christian Unity on January 25, 1959, Pope John XXIII said that he desired "to invite the separated Communities to seek again that unity for which so many souls are longing in these days throughout the world." $\stackrel{5}{-}$ In his address to open the Council, he once again mentioned other faith communities. ${ }^{-}$Pope Paul VI's address to the opening of the second session of the council continued the agenda of Pope John XXIII. There he spoke of his "deep sadness" at the "prolonged separation" of the communities of the non-Catholic observers and the Catholic Church, saying that "if we are in any way to blame for that separation, we humbly beg God's forgiveness and the pardon too of our brethren who feel they have been injured by us." - Paul VI enumerated four objectives for the council: the awareness of the church, its reform, the bringing together of all Christians in unity, and the dialogue of the church with the contemporary world.

The first document to be promulgated by the council, the Constitution on the Sacred Liturgy (Sacrosanctum Concilium), cites in its very first paragraph ecumenical unity as one of the goals of the council when it says that one of the council's intentions is "to encourage whatever can contribute to the union of all who believe in Christ." ${ }^{\prime}$ In addition, three later documents of the council contributed in a direct way to Catholic ecumenical 
engagement: the Dogmatic Constitution on the Church (Lumen Gentium), the Decree on Religious Freedom (Dignitatis Humanae), and the Decree on Ecumenism (Unitatis Redintegratio).

Lumen Gentium acknowledges the presence of ecclesial elements outside the visible boundaries of the Catholic Church, stating that the church of Christ "subsists in" the Catholic Church, although "outside its structure many elements of sanctification and of truth are to be found which, as proper gifts to the church of Christ, impel towards catholic unity." $\underline{9}$ This acknowledgement of ecclesial elements provides an important basis for ecumenical dialogue and represents a development from the papal encyclical of Pius XII, Mystici Corporis, which identified the church of Christ with the Roman Catholic Church. $\underline{10}$ Although the meaning and intent of the phrase "subsists in" has been much discussed, the Congregation for the Doctrine and the Faith confirmed that it means

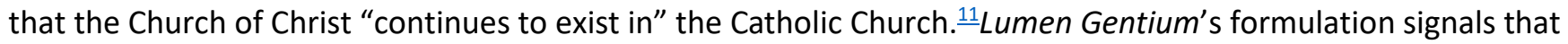
ecclesiality does not simply coincide with the Catholic Church. Although the Catholic Church explicitly recognizes some communities as properly being churches on account of their ministry in apostolic succession, the status of communities issuing from the Reformation remains a topic of ecumenical conversation. Ecumenical agreements on baptism, the Eucharist, apostolicity, ministry, the creeds, and the nature of the church as a communion suggest that it is time for the Catholic Church to formally recognize some of these Reformation communities as churches.

Dignitatis Humanae elicited new confidence in ecumenical relationships by eliminating a previously assumed double standard under the principle that "error has no rights" 12 by which the church enjoys freedom when it is a minority and exercises intolerance when it is a majority. $\frac{13}{3}$

Unitatis Redintegratio positively recognizes other Christians and effectively destroys an all-or-nothing approach to the recognition of the sacramental life of separated Christian communities. It asserts, "Our separated brothers and sisters also celebrate many sacred actions of the Christian religion. These most certainly can truly engender a life of grace ... and must be held capable of giving access to that communion in which is salvation." 14 It concludes this thought by saying, "It follows that the separated churches and communities as such, though we believe them to be deficient in some respects, have by no means been derived of significance and importance in the mystery of salvation" (ibid.). In some measure, through these shared elements, the one church of Christ is present and operative in these separated Christian churches and communities, albeit imperfectly. $\frac{15}{}$

The ecumenical initiatives of the council bore fruit. The Joint Working Group between the Catholic Church and the Lutheran World Federation came into existence in 1965, the same year as the conclusion of the Second Vatican Council. Since then, the International Lutheran-Roman Catholic Commission on Unity has issued nine reports: The Gospel and the Church (1972), The Eucharist (1978), All Under One Christ (1980), Ways to Community (1980), The Ministry in the Church (1981), Martin Luther: Witness to Christ (1983), Facing Unity: Models, Forms and Phases of Catholic-Lutheran Church Fellowship (1984), The Joint Declaration on the Doctrine of Justification (1999), and The Apostolicity of the Church (2006). Numerous statements have also been issued from the International Dialogue between the Catholic Church and the Word Alliance of Reformed Churches, $\underline{\underline{16}}$ the International Dialogue between the Anglican Communion and the Roman Catholic Church,,$\underline{17}$ and the International Commission for Dialogue between the Roman Catholic Church and the World Methodist Council. $\underline{18}$ Roman Catholics have also been in dialogue and produced statements with ecclesial communities representing a more congregationalist church structure, including the Disciples of Christ, Baptists, Pentecostals, and Evangelicals. In a multilateral context, the Joint Working Group of the World Council of Churches and the Roman Catholic Church has also produced a number of statements. Finally, national bi-lateral conversations also have contributed to the growing volume of ecumenical agreements, which now comprises the material of an emerging subdiscipline within theology. Although its purpose is to promote the unity and communion of these 
traditions, the issue of reception, that is, moving from agreed documents to shared ecclesial life, remains a problem yet to be solved.

\section{The Challenges of Reception}

Reception of the results of ecumenical dialogue remains one of the chief challenges of the ecumenical movement. Reception, far more than official responses to dialogue results, is an all-compassing process of churches making their own the results of their encounter with one another, especially "the convergences and agreements reached on issues over which that have been historically divided." $\underline{19}$ The churches discern, appropriate, and assimilate what is received through concrete acts of communion such as signed agreements, common celebrations of the Eucharist, pulpit exchanges, and profession of common creeds. Even after official acts of reception, reception requires assimilation into the life of the church so that what is received shapes a church's life and mission. This takes time.

To date, the Roman Catholic Church has officially received only one ecumenical agreement reached with an ecclesial community issuing from the Reformation: the Joint Declaration on the Doctrine of Justification, signed on October 31, 1999 by representatives the Catholic Church and the Lutheran World Federation. ${ }^{20}$ The key agreement of the Joint Declaration states, "Together we confess: By grace alone, in faith in Christ's saving work and not because of any merit on our part, we are accepted by God and receive the Holy Spirit, who renews our hearts while equipping and calling us to good works." $\underline{21}$ By signing the Official Common Statement, the two partners in dialogue confirm that they have reached a high level of consensus in basic truths regarding the doctrine of justification. They also declare that the mutual condemnations from the time of the Reformation concerning the doctrine of justification do not apply to the teaching on justification as set forth by Lutherans and Roman Catholics in the Joint Declaration.

The significance of this event is evident when we recall that a doctrinal condemnation, the authoritative declaration that a difference with regard to a particular teaching is of such grievous nature that it divides the church, represents the highest degree of escalation in theological controversy within a church or between churches. Doctrinal condemnations confirm and seal church division. On the other hand, the declaration of nonapplicability of a doctrinal condemnation means that the ecumenical dialogue has reached a point where the difference with regard to a particular teaching has lost its edge so that this remaining difference is no longer church-dividing. The Joint Declaration now serves as the foundation and point of departure for all subsequent ecumenical agreements by Lutherans and Catholics. The World Methodist Council subscribed to the Joint Declaration in 2006. $\underline{22}$

\section{The Declaration on the Way}

The Declaration on the Way, the product of a project undertaken with sponsorship of the Evangelical Lutheran Church of America (ELCA) and the United States Conference of Catholic Bishops (USCCB), identifies thirty-two convergence statements culled from both international and regional dialogues regarding church, ministry, and Eucharist. $\underline{23}$ It then provides the foundation for those agreements from ecumenical statements spanning the past fifty years, and then more tentatively indicates considerations for possible ways forward regarding a select number of remaining differences.

The original idea for such a document actually originated with Cardinal Kurt Koch, President of the Pontifical Council for Promoting Christian Unity (PCPCU), who proposed trying a new genre of ecumenical writing, a "declaration on the way," with the suggestion that this approach specifically be used on the vital and difficult issues of church, ministry, and Eucharist. Such a declaration would be an "in between" sort of document, not as definitive as the Joint Declaration, but one that would identify and claim, more forcefully than a series of separate dialogue statements, the real if incomplete agreement already reached through ecumenical dialogue. 
The ELCA then proposed the project to the Secretariat for Ecumenical and Interreligious Affairs at the USCCB, who accepted the proposal. A task force, distinct from the current Lutheran-Catholic dialogue, was appointed to produce the document.

Neither a consensus document like the Joint Declaration, nor simply another dialogue statement from the national bilateral dialogue, the Declaration on the Way represents a new genre of ecumenical statements as a sort of interim document. It is "on the way" because it marks the progress achieved in fifty years of dialogue by identifying statements of consensus while simultaneously acknowledging that full agreement has not yet been reached on all aspects of these topics. The document itself is in via since the final destination of full agreement and full, visible communion still lies ahead.

The Declaration on the Way was overwhelmingly accepted by the 2016 ELCA Churchwide Assembly by a vote of 931 to 9 and was endorsed unanimously by the USCCB's Ecumenical Committee. Although the hope is that it will be received and endorsed internationally, the origin of the Declaration on the Way as a project carried out by a task force appointed by the USCCB and the ELCA creates the problem of how to advance a document of national origin for international reception, since neither the LWF nor the PCPCU has the practice of officially receiving national statements.

Several avenues are possible for reception that honor its character as a document in via as contrasted with a consensus document. The General Council of the Lutheran World Federation could possibly receive it, which would be a lesser reception than occurred with the Joint Declaration, where the LWF initiated a process of gathering the ratification of its member churches and then confirming that ratification. The Lutheran-Catholic Commission on Unity could commend it back to the PCPCU for reception. Another possibility for international reception might be study of the document by other national ecumenical commissions and then formation of an expanded drafting group with international representation to develop the document further. Although the goal is the reception and affirmation of the list of thirty-two statements of agreement on church, ministry, and Eucharist by the Lutheran World Federation and the Roman Catholic Church, at this point avenues for reception are still being explored.

\section{The Quest for Full Communion}

For the past 500 years, the experience of division has been more familiar then any experience of unity. In spite of fifty years of dialogue, there is no clear agreement on how much agreement would allow full communion or even on how much partial communion would suffice for expanded opportunities for eucharistic sharing.

In Facing Unity, the Roman Catholic-Lutheran Joint Commission begins to answer these questions. It identifies these elements of full communion: (1) community of faith, including joint witness to the apostolic faith, unity of faith in diversity of form, and the removal of doctrinal condemnations; (2) community in sacraments, including agreement in the understanding and celebration of sacraments; (3) community of service, including structured fellowship, mutual recognition of a common ordained ministry, joint exercise of episcope, acts of recognition, an initial Act of Recognition, and a single episcopē exercised in collegial form. These same elements also occur in another Roman Catholic-Lutheran document, The Ministry in the Church, which lists as the preconditions for acceptance of full communion "agreement in the confession of faith-which must also include a common understanding of the Church's ministry-a common understanding of the sacraments, and fraternal fellowship in Christian and Church life." $\underline{24}$

The ELCA offers more detail in describing the requirements for full communion with their practical implications, recognizing that some of these exist at earlier stages of communion: (1) a common confessing of the Christian faith; (2) a mutual recognition of baptism and the sharing of the Lord's supper, allowing for joint worship and in exchange ability of members; (3) a mutual recognition and availability of ordained ministers to the service of all 
members of churches in full communion, subject to the disciplinary regulations of other churches; (4) a common commitment to evangelism, witness, and service; (5) a means of common decision-making on critical common issues of faith and life; and (6) a mutual lifting of any condemnations that exist between the churches..$\underline{25}$

Many North American Lutherans were in committed ecumenical partnerships as early as $1950 . \frac{26}{}$ At its eleventh biennial convention in 1982, the Lutheran Church in America promulgated Ecumenism: A Lutheran Commitment, outlining its ecumenical charter. Three years later, The American Lutheran Church approved a similar document entitled, Ecumenical Perspective and Guidelines. The Evangelical Lutheran Church of America (ELCA), formed by the union of these two church bodies and the Association of Evangelical Lutheran Churches in 1988, issued the statement The Vision of the Evangelical Lutheran Church in Americain which the ECLA describes itself as "evangelical," "catholic," and "ecumenical," and states that "its confessional character is not opposed to its ecumenical commitment, but necessitates it as a consequence of the Gospel." 27 Current full communion partners with the ELCA include the Presbyterian Church (USA) (1997), the Reformed Church in North America (1997), the United Church of Christ (1997), the Episcopal Church (1999), the Moravian Church (1999), and the United Methodist Church (2009).

In forging relationships of full communion with the Episcopalians and Anglicans, a number of Lutherans have made agreements to enter into episcopal apostolic succession. The American concordat document, Called to Common Mission (1999), provides for the participation of Anglican bishops in historic succession in the consecration of Lutheran bishops, and also establishes the mutual recognition and thus interchangeability of ministry between the two traditions. $\frac{28}{\text { Th }}$ This agreement did not require Lutherans to repudiate their former ministers or ministries. Despite this interchangeability, the two communions remain distinct, and maintain parallel structures of authority, institutional life, and communion. The closest Catholic analog to this practice is the existence within the Roman communion of the various Churches, each of which has its own liturgy and clergy. When the need arises, these Churches can grant faculties to a priest from another Church, thus making him "bi-ritual" thanks to a differentiated relationship to more than one bishop.

At a worldwide level, the Porvoo Common Statement (1993) provides a framework for practical unity between European Anglican and Lutheran churches. $\underline{29}$ It closes with the Porvoo Declaration, which acknowledges a common faith, confession, sacrament, and ministry. The signatory churches commit themselves to expanding cooperation and mutual action, including participation in one another's ordinations, the mutual recognition of one another's ministers, a common participation in mission, and joint ecumenical initiatives.

While helpful to some extent, the criteria for full communion mentioned above are not specific enough to determine when full communion has been reached between Lutherans and Catholics. Although they profess the same creeds, and the doctrinal condemnation concerning justification has been declared inapplicable in the Joint Declaration, differences remain regarding specific beliefs related to the topics of church, ministry, and Eucharist. $\stackrel{30}{-}$ The question of how much diversity can coexist with full communion has no clear answer. Here, a hermeneutic of generosity is needed. Unfortunately, church schism is a bit like divorce, where perhaps more differences are tolerated before the divorce, but even greater agreement is required to mend the division.

\section{New Ecumenical Methodologies}

The maturation of dialogue has resulted in new ecumenical methodologies. These include the concept of a differentiating consensus used with success in the Joint Declaration, the move from comparative theology to a more constructive theology, and most recently, Paul Murray's proposal for receptive ecumenism. 


\section{Differentiating Consensus}

In addition to the doctrinal agreement reached in the Joint Declaration, the document also represents an achievement in ecumenical methodology, namely, what has come to be known as a differentiated or differentiating consensus, a model and method now available to future ecumenical agreements. $\stackrel{31}{1}$ The concept of differentiated consensus derives from the work of the Tübingen scholar, Johann Adam Möhler, who in his early work, Die Einheit in der Kirche (1825), distinguished between complementary oppositions (Gegensätze) and heretical contradictions (Widerspräche) incompatible with the faith of the church.

Within a differentiating consensus, a common statement is followed by a statement: "When Catholics affirm ' $x$,' they do not exclude ' $y$,' and when Lutherans say ' $y$,' they do not exclude ' $x$.'" A differentiating consensus acknowledges a consensus on some basic truths, while at the same time acknowledging that "remaining differences of language, theological elaboration, and emphasis" $\underline{\text { "2 }}$ fall within an acceptable diversity and do not destroy the consensus on the basic truth. $\underline{33}$ Such a "differentiated consensus" offers a common understanding of a doctrinal point while acknowledging legitimate, permissible, and even meaningful differences of formulation by the two traditions arising from their respective conceptual frameworks. The method does not imply doctrinal uniformity, but within it Catholic and Lutheran teaching represent different doctrinal "configurations" that are open to each other and that express the same theological concerns. $\frac{34}{4}$

\section{Constructive Theology Rather than Comparative Theology}

Ecumenical theology began largely as a comparative enterprise, which examined what each partner held on a particular topic, examining those teaching for similarities and differences. Once dialogue had engaged the major topics, however, a shift occurred to emphasize what the two traditions could teach together on a given topic. For example, the present US Lutheran-Catholic dialogue is addressing the topic "Ministries of Teaching," the international Lutheran-Catholic Commission on Unity is working on "Baptism and Growth in Communion" to ascertain how much communion can be claimed on the basis of our mutual agreement on baptism, and the North American Orthodox-Catholic Dialogue is working on a baptismal ecclesiology of the Christian faithful that supports an expanded practice of conciliarity and synodality. In each case, ecumenical dialogue has moved beyond simple comparative theology to engage in a common constructive theology. The emphasis is on what ecclesial traditions can say together on the basis of their achieved degree of communion.

\section{Receptive Ecumenism}

The brainchild of Paul D. Murray and the product of a research project of the Durham Centre for Catholic Studies in collaboration with colleagues in Australian, European, and North American institutions, $\frac{35}{2}$ receptive ecumenism is a mutual process wherein each tradition seeks first what it can learn from another tradition before it attempts to teach that tradition what we think they need to learn from us. The responsibility for learning lies first with the self, not the other tradition with which we are in dialogue. The self-critical question is, "What can we learn, or receive, with integrity from our various others in order to facilitate our growth together into deepened communion in Christ and the Spirit?" 36 The spirit is one of a mutual gift exchange, much in the spirit of John Paul II's description of dialogue: "Dialogue is not simply an exchange of ideas. In some way, it is always an exchange of gifts." 37 The emphasis, however, is on receiving rather than giving, asking what our tradition needs to learn from another rather than what they need to learn from us.

Since 2006 there have been three international conferences devoted to the methodology: "Receptive Ecumenism and the Call to Catholic Learning" (Durham, 2006); "Receptive Ecumenism and Ecclesial Learning" (Durham, 2009); and "Receptive Ecumenism in a North American Context" (Fairfield, CT, 2014). $\frac{38}{\text { While a method }}$ that until now has not influenced official bilateral dialogues, the Anglican-Roman Catholic International Commission (ARCIC) is trying out the method in its current round. Since the results are not yet available, it remains to be seen how useful the method is for official bi-lateral dialogues. 
Any method proper to ecumenical engagement requires approachability, readiness for dialogue, patience, and a hermeneutic of generosity, the same characteristics advocated by Pope Francis for catechesis, Christian initiation, and Christian formation in general. ${ }^{39}$ Although no tradition is asked to surrender its core beliefs, each must remain open to examining those beliefs in the light of new relationships, new contexts, and new historical and theological insights.

\section{Principles of Ecumenical Dialogue}

Fifty years of dialogue have also resulted in the recognition of a number of helpful principles for dialogue. For example, when the binding positions of two traditions appear to be in conflict, it is instructive to examine what truth of the Gospel those binding positions protect. This may lead to a deeper common understanding of the Gospel at the same time that it may relativize contingent practices adopted to protect the deeper value. As an example, this principle may shed light on the practice of presbyteral ordination at the time of the Reformation and changes in the office and exercise of episcope at the time. The Reformers considered themselves to be faced with a decision between fidelity to the Gospel, or continued episcopal ordinations at the price of conscience, since no bishop in communion with Rome would ordain a minister with Reformation sympathies. They were also following the position of Jerome, who held that there was no essential difference between a presbyter and a bishop, except for jurisdiction. $\underline{40}$

Second, it is important to discern the type of theological discourse under consideration. Otto Pesch helpfully differentiates between Lutheran theology identified as an existential theology from Roman Catholic theology, identified as sapiential theology. ${ }^{41}$ Broadly speaking, existential theology has as its starting point the act of faith and its theoretical implications. Directed to one's one existential self-accounting before God, it looks from the human person toward God and then from God back to the human person, operating prototypically within an IThou framework and only consequently and derivatively in the third person. Its primary genre is one of confession, and with respect to salvation, it stresses faith, humility, and repentance. $\frac{42}{}$ Existential theology occurs in the context of prayer, such that "every theological statement is in fact a variation on a word spoken in prayer and can be easily transformed into prayer by a simple change in its grammatical form." 43 Pesch consequently asserts, "prayer becomes the norm in judging the legitimacy of theological affirmations." $\underline{\text { "In }}$ contrast to this, sapiential theology, attributed by Pesch to Thomas Aquinas, is directed to "wisdom," in the medieval sense of understanding through ultimate causes. Its perspective is that of God looking upon the human person. It speaks descriptively in the third person. $\frac{45}{4}$

Existential theology cannot be evaluated according to the "grammar" of sapiential theology and vice versa. For example, Catholics have too frequently evaluated the Lutheran teaching of simul iustus et peccactoragainst a metaphysical ontology which judges that one cannot occupy two conflicting states of being simultaneously, although within the language and experience of prayer no other posture is possible for a Christian insofar as we do not proclaim our own righteousness before God.

Third, the principle of the hierarchy of truths, enunciated in Unitatis Redintegratio 11, is necessary to achieve "a fitting sense of proportion" in evaluating the confessional commitments of our dialogue partner (EG 33-39, 246). As Pope Francis insists, only when a focus on the foundation of faith is maintained can the rich doctrinal teaching, including moral and social teachings, be rightly understood. Rather than getting bogged down in a disjointed multitude of intricate doctrinal details, churches can and must unite around a simplified message of the Gospel. This does not mean setting aside any of the rich heritage of the church's teaching and tradition, but rather relating individual truths to the "harmonious totality of the Christian message" (EG29). 


\section{A Tale of Ecumenical and Ecclesial Fragmentation}

In addition to agreements of full communion, a changing ecclesial landscape characterized by mergers and ecclesial fragmentation is impacting efforts to achieve unity among Christian churches.

\section{Lutheran Merger and Fragmentation}

The history of Lutheran synods in the USA recounts a story of fragmentation and merger. ${ }^{46}$ The original fragmentation of Lutheran synods was due to the national, linguistic, and ethnic origins of the Lutheran immigrants, but continued assimilation into an American culture fostered a movement toward a series of mergers in the nineteenth century. These reached their culmination in 1988 with the formation of the Evangelical Lutheran Church in America (ELCA) from a merger in 1988 of the American Lutheran Church (ALC), and the Lutheran Church in America (LCA), and the Association of Evangelical Lutheran Churches (AELC), which split from the Lutheran Church-Missouri Synod in 1976 over differences regarding scriptural interpretation. ${ }^{47}$ Of the American Lutheran groups, the Evangelical Lutheran Church in America (ELCA), the largest, is a member of the Lutheran World Federation, and is the Lutheran church with which the Roman Catholic Church in the United States is in dialogue. The Lutheran Church-Missouri Synod (LCMS), originating from German immigrants and dating from 1847, is the next largest group, followed by a much smaller Wisconsin Evangelical Lutheran Synod (WELS), dating from 1850. Fractures in the twenty-first century resulted in the most recent group, the North American Lutheran Church (NALC), formed in 2010. The ELCA, LCMS, and WELS are not in full communion with each other. It should also be noted that LCMS and WELS are among the minority of worldwide Lutheran church bodies who do not belong to the Lutheran World Federation and thus are not signatories to the Joint Declaration on the Doctrine of Justification.

An account of the differences between WELS and LCMS and other Lutheran groups illustrates the ecumenical challenge posed by confessional positions resulting in ecclesial divisions even within a particular ecclesial tradition. Members of WELS may not participate in ecumenical prayer services or pray with people outside their own synod as a result of their interpretation of Romans 16:17-18:

I urge you, brothers and sisters, to watch out for those who cause divisions and put obstacles in your way that are contrary to the teaching you have learned. Keep away from them. For such people are not serving our Lord Christ, but their own appetites. By smooth talk and flattery they deceive the minds of naive people [NIV]

WELS believes that Jesus Christ commands believers not to practice church fellowship with people who persist in false teaching or false beliefs. LCMS distinguishes between altar and pulpit fellowship and other forms of prayer and Christian fellowship, on the one hand, and between Christian fellowship and prayer with non-Christians, on the other hand. It allows the first and prohibits the second. Pastors belonging to LCMS were disciplined by church authorities for participating in public interfaith prayer services after the terrorist attacks on the World Trade Center in 9/11 and also after mass shootings at Sandy Hook Elementary School in Newton, Connecticut in 2012. WELS does not make such a distinction, prohibiting shared prayer beyond their synod membership, whether with other Christians or with non-Christians.

Sometimes agreements for the purpose of unity result in further divisions within an ecclesial tradition. By a margin of twenty-three votes over the required two-thirds majority, the ELCA voted in 1999 to accept the document Called to Common Mission, which called for a laying on of hands by bishops installed into the historic episcopate, understood to be a sign but not a guarantee of apostolic succession. While the agreement enabled the ELCA to enter into full communion with the Episcopalians, the action elicited opposition from some Lutherans, who organized the Word Alone Network. This became a voice for opposition in the ELCA before eventually disbanding and helping to create in 2001 a new Lutheran group, the Lutheran Congregations in 
Mission for Christ (LCMC), which was intended to be more an association of congregations than a traditional Lutheran synod. In 2017 this group numbered 931 congregations. $\underline{48}$

A more recent split from the ELCA resulted in the formation in 2010 of the North American Lutheran Church (NALC) as a result of the 2009 vote by the ELCA churchwide assembly vote on sexuality permitting the ordination of LGBTQ ministers in same-sex monogamous relationships. This last vote was a mere two votes over the twothirds majority. NALC in 2016 had grown to more than 400 congregations, of which 70 are missionary congregations. $\frac{49}{}$ Although the two groups formed for different reasons, the historian Mark Granquist calls the combined schism that produced the NALC and the Lutheran Congregations in Mission for Christ (LCMC), which has a less traditional synodical organization, "the largest American Protestant schism since the nineteenth century." $\underline{50}$

The disputes that divide the Lutheran churches in the USA today were not Lutheran issues in the sixteenth century confessional documents. In addition to the sexuality issues resulting in the formation of the NALC, biblical interpretation continues to be a divisive difference between the ELCA and WELS and LCMS. The issue is the extent to which the Bible can be interpreted using the tools of modern biblical exegesis; for example, the extent to which the Bible reflects multiple human authors and editors, contains much of the worldview of its time, exhibits internal inconsistences and errors of fact, and allows for the possibility of accepting the demonstrations of modern science such as biological evolution. Conservative defenders of biblical authority hold to a more literal interpretation of the Bible, including its account of creation in six days. Increasingly, conservative defenders of the Bible argue that the Bible must be completely true in all respects. $\underline{51}$

This dispute about the authority of Scripture centers on two biblical concepts, that of "inerrancy" and "infallibility." "Inerrancy" sometimes means that Scripture is the "supreme source and norm," a liberal interpretation, while to conservatives it means that the Bible is without error in any matter whatsoever. $\frac{52}{}$ For example, while the LCMS does not hold the position that everything in the Bible is to be taken literally, it also says that there is nothing in the Bible to suggest that the creation account is not to be taken literally:

The Synod has affirmed ... that "God by the almighty power of His Word created all things in six days by a series of creative acts," that "Adam and Eve were real, historical human beings, the first two people in the world," and that "we must confess what St. Paul says in Rom 5:12" about the origin of sin through Adam as described in Genesis 3 (1967 Synodical Resolution 2-31). The Synod has also, therefore, stated that it rejects "all those world views, philosophical theories, exegetical interpretations and other hypotheses which pervert these biblical teachings and thus obscure the Gospel" (1967 Synodical Resolution 2-31). $\underline{53}$

The Wisconsin Evangelical Lutheran Church (WELS) rejects factual errors in Scripture and expresses this interpretation of inerrancy:

We reject any thought that makes only part of Scripture God's Word or that allows for the possibility of factual error in Scripture, even in so-called nonreligious matters such as historical or geographical details. We likewise reject all views that say Scripture is merely a human record of God's revelation as he encounters mankind in history, and so is a record subject to human imperfections. $\underline{54}$

Since the Wisconsin Evangelical Church (WELS) suspended fellowship with the Missouri Synod (LCMS) in 1961, both bodies have engaged in conversation informally since 2012 to better understand one another. This coincides with the ecumenical agenda of LCMS's most recent president, Matthew C. Harrison, elected in 2010. Under his leadership, the LCMS is cultivating relationships with a number of groups with conservative social agendas such as The Lutheran Church Canada (LCC), the Anglican Church in North America (ACNA), and the North American Lutheran Church (NALC). 
Lutherans are not unique in their internal fragmentation, for the past few decades have also seen tendencies toward both fragmentation and merger within the Anglican churches largely due to debates over human sexuality and ministry. ${ }_{5}^{5}$ The tale of merger, fragmentation, and shifting alliances of communion illustrates the complex relationship of weakened or failed communion within denominational identities that co-exists with strengthened ties of communion inter-denominationally. Efforts for unity are frequently more vigorous across denominational differences than within the same family of churches.

\section{The Commemoration of 2017 and Ecclesial Divisions}

The various themes for the commemoration of 2017 diversely reflect various interpretations of the Confessions as well as the social divides separating the churches. The theme of the LWF's Twelfth Assembly-the event where the LWF will commemorate 2017 at a global level-is "Liberated by God's Grace," with three subthemes: Salvation-Not for Sale; Human Beings-Not for Sale; and Creation-Not for Sale. The connection between the theological message of the Reformation of justification by faith though grace and the social agenda of human trafficking and slavery and the theme of care for creation through environmental concerns is immediately evident. The LWF emphasizes that the observance of the quincentenary of the Reformation is a "commemoration" and not a "celebration." Its three principles are that the commemoration is ecumenically engaged and accountable (which explains why it is a commemoration and not a celebration); that the Lutheran movement is now global; and that "reforming" is ongoing. The ecumenical engagement is evident in the book, From Conflict to Communion, written by the Lutheran-Roman Catholic Commission on Unity for the commemoration, as is a prayer service based on this document prepared by Lutherans and Roman Catholics for the ecumenical commemoration of 2017. $\underline{56}$

For the anniversary, the ELCA is emphasizing the theme of the liberating power of the promise of God's mercy freely given in Christ with no condition of human qualification, preparation, or response. The ELCA stresses the message of the liberating power of faith "in a culture that assumes a faith relationship with God is an act of human 'free will.'" The conviction is that "the distinction between law and promises liberates Christians from legalistic interpretations that trap people in judgment, condemnation and exclusion from God's mercy in Christ." $\underline{57}$ Thus, the subtext of the ELCA's commitment to the full inclusion of various ethnic, racial, and gender diversities is evident the theme of the ELCA's assembly in August 2016: "Freed and Renewed in Christ: 500 Years of God's Grace in Action."

LCMS is calling the five hundredth anniversary a celebration of the Gospel, not a commemoration, and its theme is "It's Still All about Jesus." Desiring to provide a conservative Lutheran option in Wittenberg, the LCMS, the International Lutheran Society of Wittenberg (a German nonprofit corporation owned by the LCMS), Concordia Publishing House, and the Independent Evangelical Lutheran Church, a LCMS partner church in Germany, are renovating Wittenberg's Old Latin School for use as a ministry center for evangelism.

This overview of how the LWF, the ELCA, and the LCMS are commemorating the anniversary of the Reformation in 2017 reveals the different agendas of the three groups, the first two incorporating a social agenda as an extension of the confessional doctrinal beliefs, with the latter limiting itself to evangelization more narrowly conceived. The ELCA would be quick to agree with LCMS that the commemoration in 2017 is still about Jesus, but would point out that Jesus preached God's reign of justice, inclusive of social realities.

\section{Conclusions regarding the Shifting Ecclesial Landscape}

Despite the numerical dominance of the Lutheran World Federation in global membership and the ELCA in US membership, Lutheran communities are experiencing fragmentation and a lack of communion among themselves, in part because of the ELCA's strong commitment to building ecumenical relationships. Ironically, ecumenical commitments not only contribute to church unity; in some instances, they have contributed to 
disunity. The LWF and the ELCA have been practicing ecumenical and interreligious outreach, while the LCMS is defining the Lutheran Confessions and the Bible as the basis of ecumenical outreach, and is seeking to solidify alliances with conservative confessional Lutherans. The current ecclesial climate reflects the polarization of the political climate and the broader culture wars, with fault lines dividing along issues of sexuality, the role of women, and church polity.

The Confessions themselves do not constitute the dividing line between the ELCA and the LCMS, but the two churches differ in their interpretation of them, the LWF and the ELCA holding that social concerns are a legitimate extension of confessional principles. Also contributing to division, however, is the willingness of the ELCA to enter into relationships of full communion with churches that do not subscribe to the Confessions, such as Anglicans, Methodists, and the Reformed. Ironically again, ecumenical efforts toward unity themselves have become church-dividing; the ELCA's acceptance of Called to Common Mission and its adoption of the historic episcopate contributed to the split between the NALC/LCMC in the 2000s. That Lutheran churches cannot commemorate 2017 together represents a tragic moment in this centenary, a stark contrast to a century ago when the celebration of the Reformation led to the formation of the United Lutheran Church in America (ULCA) in 1918 in commemoration of the 400th anniversary of the Reformation, $\underline{58}$ and indirectly, to the formation of the Norwegian Lutheran Church, a predecessor body to the American Lutheran Church (ALC).

Furthermore, on the broader ecumenical scene, even as old divisions are mended through long and patient dialogue, new differences emerge in contemporary times. Issues such as the ordination of women, questions of sexuality, and moral issues such as abortion and end-of-life ethics are potentially divisive and impede progress on some of the older theological issues. The expansion of the theology of ordained ministry in Vatican II, the revision of ordination rites as a result of historical work on the history of the liturgy, and the reconciliation with respect to the notion of eucharistic sacrifice through the concept of anamnesis suggest that an evaluation of Anglican orders might take a different path in the twenty-first century than in 1896, when Leo XIII declared them null. Yet, the ordination of women is the elephant in the room that prevents such an evaluation.

Likewise, historical work on the exercise of episcope at the time of the Reformation, as well as advances in an understanding of the interrelationship between the apostolicity of the church and apostolic ministry, have brought Lutherans and Catholics closer together on these issues. But the question of who can be ordained prohibits a resolution of the mutual recognition of ministry. All too often, traditional divisive issues such as apostolic succession may still be approached through old lenses emphasizing a physical succession of ministers to the exclusion of an apostolic succession of communities intent upon retaining apostolicity by other means, such as worship, creeds, Scripture, and life. While a decision of conscience at the time of the Reformation led to a break in episcopal ordinations, apostolicity has been shown to be more complex and multifaceted than a onesided emphasis on succession of ministers may suggest. $\underline{59}$

\section{Moving Forward Ecumenically}

Moving forward, it will be important not to simply look at absolute equivalencies in doctrinal language, but to discern deeper commonalities among ecclesial traditions. For example, while Lutherans recognize only two sacraments, baptism and Eucharist, they celebrate rituals that Catholics call sacraments, sometimes with the same prayer texts and with the same intention, such as in confirmation. This deep commonality so overrides the formal recognition of the rite as a sacrament such that the difference should not be considered to be churchdividing.

Second, it will also be important to correlate doctrines mutually rather than to address them in isolation from one another or to evaluate them uni-directionally. For example, theologians commonly affirm that apostolicity is carried by the church as well as by ministry in apostolic succession. Thus, recognition of ministry depends upon 
the recognition of the ecclesiality of a community and not only the recognition of communities upon a recognition of ministry. Ministry also correlates with what the community understands itself to do when it celebrates the sacraments. In this case, recognition of a community's sacraments does not simply depend upon a recognition of its ministry, but the recognition of its ministry is related to an understanding of that community's sacraments and its self-understanding as a church. $\underline{\underline{60}}$

Third, since the first round of ecumenical gains has run its course, perhaps the churches now need a next stage that requires a different kind of engagement and reception. Where the emphasis in the past has been on achieving doctrinal agreement, now the gains achieved by doctrinal consensus must be paired with what might be termed a "pastoral ecumenism." One example of this would be eucharistic sharing within an ecumenical marriage. The Catholic Church recognizes the marriage between a Lutheran and a Catholic to be sacramental at the same time as it recognizes marriage to signify the relationship between Christ and his church. Does this marriage not constitute an at least inchoate relationship between the Lutheran spouse and the Catholic Church? Would not this implicit relationship with the church, a common belief in the real personal presence of Christ in the Eucharist, and the spiritual need of spouses to be nourished by the Bread of Life indicate the appropriateness of their receiving the Eucharist together, particularly given the imperfect communion recognized between Lutherans and Catholics?

Additional pastoral practices need to be identified and adopted to reflect and live into doctrinal agreements already achieved. Since "communion" is not an all-or-nothing concept, but allows for gradations, the life and practices of communities in a relationship of imperfect communion should reflect the degree of communion achieved. All churches are experiencing internal disagreements that exist alongside their efforts toward ecumenical communion. Churches need to reflect on whether they require of their ecumenical partners what they are unable to achieve within their own ecclesial house.

The tale of two cities, the city of ecumenical progress and the city of continued ecclesial fragmentation, is not likely to achieve resolution this side of the eschaton. Nevertheless, churches can choose unity over division, reconciliation over animosity, and dialogue over mutual condemnations. The tragedy of church division is not ecclesial diversity per se, but rather the failure to recognize in other Christians a common faith and commitment to God, Jesus Christ, and the Holy Spirit. Ecumenism and the prayer and work for Christian unity that it entails is neither an ecclesial option nor merely an academic exercise. In addition to the scholarly and technical work of achieving consensus in doctrine, churches must live into the communion they already experience instead of waiting until full agreement and consensus are reached. Excessive ecclesial timidity in this regard is no better than rash action that runs ahead of ecumenical agreements.

The hermeneutic of generosity already mentioned as well as an ecclesial virtue of humility $\underline{\underline{61}}$ require a hierarchy of virtues that complements the hierarchy of truths..$\underline{62}$ Within such a hierarchy, love reigns. Love seeks unity and communion in spite of sin, differences, and the general messiness attendant upon a pilgrim church. What is essential is that the churches and their ecumenical partners resolve to remain in dialogue and in mutual discernment of the Gospel. The need for a common witness to Christ in a secular and non-Christian world is greater than the divisions within the churches. Seen from outside the walls of these churches, outside the commonality that labels these communities "Christian," belief in Christ and the Trinity is a much greater commonality than what appears from the outside to be intra-mural bickering about technical issues of which even many believers know little. Ecumenical efforts toward Christian unity provide a powerful witness to peace and reconciliation in a violent, war-torn world. As Gaudium et Spes states, "We are also mindful that the unity of Christians is today awaited and desired by many non-believers. For the more this unity is realized in truth and charity under the powerful impulse of the Holy Spirit, the more will it be a harbinger of unity and peace throughout the whole world." $\underline{63}$ 


\section{References}

1. Lutheran-Roman Catholic Commission on Unity, From Conflict to Communion: Lutheran-Catholic Common Commemoration of the Reformation in 2017 (2017),

10, http://www.vatican.va/roman curia/pontifical councils/chrstuni/lutheran-feddocs/rc pc chrstuni doc 2013 dal-conflitto-alla-comunione en.html.

2. Because the centenary of the Reformation dates to Martin Luther, this essay will focus on the Lutheran experience, and the tale of merger and fragmentation will focus on Lutheranism in the United States, since the divisions here are now being exported to other countries due to the missionary efforts of these groups. For example, the LCMS in partnership with the International Lutheran Society of Wittenberg (a German nonprofit corporation owned by the LCMS), Concordia Publishing House, and the Independent Evangelical Lutheran Church, a LCMS partner church in Germany, are renovating Wittenberg's Old Latin School for use as a ministry center for evangelism. The desire is to provide a conservative Lutheran option in Wittenberg.

3. Earlier ecumenical efforts included the Malines Conversations (the Mechelse gesprekken), an initial dialogue between Anglicans and Catholics (1921-1926) and the establishment of the ecumenical periodical Irénikonin 1926 by the Benedictine community of Chevetogne.

4. Pius XI, Mortalium Animos (January 6, 1928), 10, http://w2.vatican.va/content/piusxi/en/encyclicals/documents/hf p-xi enc 19280106 mortalium-animos.html.

5. Cited by Walter M. Abbott, "Ecumenism," in The Documents of Vatican II (New York: America Press, 1966), 336.

6. John XXIII, Humanae Salutis (December 25, 1961), https://w2.vatican.va/content/johnxxiii/la/apost constitutions/1961/documents/hf j-xxiii apc 19611225 humanae-salutis.html; English translation available at http://www.diocesecc.org/pictures/Vatican\%20Documents/humanaesalutis.pdf. Pope John XXIII established the Secretariat for Promoting Christian Unity on June 5, 1960 and appointed Augustin Cardinal Bea as its first president.

7. Paul VI, speech at the beginning of the Second Session of the II Vatican Council (September 29, 1963, Vatican City), http://www.vatican.va/holy father/paul vi/speeches/1963/documents/hf pvi spe 19630929 concilio-vaticano-ii It.html. The English citations are from Patrick Riley, "Pope Paul Sets Agenda as Council's Second Session Opens," Vatican II: 50 Years Ago Today, September 29, 2013, http://vaticaniiat50.wordpress.com/2013/09/29/pope-paul-sets-agenda-as-councils-secondsession-opens/.

8. Sacrosanctum Concilium (December 4, 1963),

1, http://www.vatican.va/archive/hist councils/ii vatican council/documents/vat-

ii const 19631204 sacrosanctum-concilium en.html.

9. Lumen Gentium (November 21, 1964),

8, http://www.vatican.va/archive/hist councils/ii vatican council/documents/vat-

ii const 19641121 lumen-gentium en.html.

10. Pius XII, Mystici Corporis (June 29, 1943), 13, http://w2.vatican.va/content/piusxii/en/encyclicals/documents/hf p-xii enc 29061943 mystici-corporis-christi.html.

11. Congregation for the Doctrine of the Faith, Responses to Some Questions regarding Certain Aspects of the Doctrine of the Church (June 29, 2007), http://www.vatican.va/roman curia/congregations/cfaith/documents/rc con cfaith doc 20070 629 responsa-quaestiones en.html.

12. The phrase was used by John Courtney Murray, in his statement: "The theory of religious tolerance takes its start from the statement, considered to be axiomatic, that error has no rights, that only truth has rights and exclusive rights. From this axiom a juridical theory is deduced, which distinguishes between 'thesis' 
and 'hypothesis.' The thesis asserts that Catholicism, per se and in principle, should be established as the one 'religion of the state' since it is the one true religion. Given the institution of establishment, it follows by logical and juridical consequence that no other religion, per se and in principle, can be allowed public existence or action within the state (which normally, in this theory, is considered to be identical and co-extensive with society). Error has no rights. Therefore, error is to be suppressed whenever and wherever possible; intolerance is the rule. Error, however, may be tolerated when tolerance is necessary by reason of circumstances, that is, when intolerance is impossible; tolerance remains the exception. Tolerance therefore is 'hypothesis,' a concession to a factual situation, a lesser evil." John Courtney Murray, "Religious

Freedom," http://www.library.georgetown.edu/woodstock/murray/1965ib.

13. John Courtney Murray, "Religious Freedom," presents three doctrinal tenets: "the ethical doctrine of religious freedom as a human right (personally and collectively); a political doctrine with regard to the functions and limits of government in matters religious; and the theological doctrine of the freedom of the Church as the fundamental principle in what concerns the relations between the Church and the socio-political order."

14. Unitatis Redintegratio (November 21, 1964),

3, http://www.vatican.va/archive/hist councils/ii vatican council/documents/vat-

ii decree 19641121 unitatis-redintegratio en.html.

15. Assertion of the doctrinal commission, Acta Synodalia III/2, 335.

16. The Presence of Christ in Church and World (1977), Towards a Common Understanding of the Church(1990), The Church as Community of Common Witness to the Kingdom of God (2007).

17. Malta Report of the Preparatory Commission (1968), Eucharistic Doctrine (1971), Ministry and Ordination(1973), Authority in the Church (1976), Eucharistic Doctrine: Elucidation (1979), Ministry and Ordination: Elucidation (1979), Authority in the Church I: Elucidation (1981), Authority in the Church II (1981), Preface to the "Final Report" (1982), Introduction to the "Final Report" (1982), Conclusion to the Final Report (1982), Clarification of Certain Aspects of the Agreed Statement on Eucharist and Ministry (1994), Salvation and the Church (1987), Church as Communion (1991), Life in Christ: Morals, Communion and the Church (1994), The Gift of Authority: Authority in the Church III (1999), Mary: Grace and Hope in Christ (2005), Growing Together in Unity and Mission (2007).

18. The Denver Report, Christian Home and Family (1971), The Dublin Report, Growth in Understanding (1976), The Honolulu Report, Toward an Agreed Statement on the Holy Spirit (1981), The Nairobi Report, Toward a Statement on the Church (1986), The Paris (Singapore) Report, The Apostolic Tradition (1991), The Rio de Janeiro Report, The Word of Life (1996), The Brighton Report, Speaking the Truth in Love (2001), The Seoul Report, The Grace Given You in Christ (2006), The Durban Report, Encountering Christ the Saviour: Church and Sacrament (2011). For texts of agreements, see the website of the Pontifical Council for Promoting Christian Unity for international dialogues or the USCCB website for the Secretariat for Ecumenical and Interreligious Affairs. For documents from US dialogues, see William G. Rusch and Jeffrey Gros, eds., Deepening Communion: International Ecumenical Documents with Roman Catholic Participation(Washington, DC: United States Catholic Conference of Bishops, 1998). For volumes containing bi-lateral ecumenical documents from a variety of ecumenical partners see Harding Meyer and Lukas Vischer, eds., Growth in Agreement: Reports and Agreed Statements of Ecumenical Conversations on a World Level (New York: Paulist, 1984); Jeffrey Gros, Harding Meyer, and William G Rusch, eds., Growth in Agreement II: Reports and Agreement Statements of Ecumenical Conversations on a World Level, 1982-1998 (Grand Rapids, MI: Eerdmans, 2000); Jeffrey Gros, Thomas F. Best, Lorelei F. Fuchs, eds., Growth in Agreement III: International Texts and Agreed Statements 1998-2005 (Grand Rapids, MI: Eerdmans, 2007). For an account of the achievements of 
these dialogues see John A. Radano, ed., Celebrating a Century of Ecumenism: Exploring the Achievements of International Dialogue (Grand Rapids: Eerdmans, 2012).

19. Joint Working Group between the Roman Catholic Church and the World Council of Churches, Reception: $A$ Key to Ecumenical Progress (June 12, 2013),

44, https://www.oikoumene.org/en/resources/documents/commissions/jwg-rcc-wcc/ninth-report-ofthe-joint-working-group; citing Joint Working Group between the Roman Catholic Church and the World Council of Churches, The Nature and Purpose of Ecumenical Dialogue (2005)

59, https://www.oikoumene.org/en/resources/documents/commissions/jwg-rcc-wcc/eight-report-ofthe-joint-working-group.

20. For a chronology of the evolution of the Joint Declaration see John A. Radano, Lutheran and Catholic Reconciliation on Justification (Grand Rapids, MI: Eerdmans, 2009).

21. The Lutheran World Federation and the Roman Catholic Church, Joint Declaration on the Doctrine of Justification (1999),

15, http://www.vatican.va/roman curia/pontifical councils/chrstuni/documents/rc pc chrstuni doc 3 1101999 cath-luth-joint-declaration en.html.

22. See The World Methodist Council Statement of Association with the Joint Declaration on the Doctrine of Justification (July 23, 2006), http://www.vatican.va/roman curia/pontifical councils/chrstuni/methcouncil-docs/rc pc chrstuni doc 20060723 text-association en.html.

23. Bishops' Committee for Ecumenical and Interreligious Affairs of the United States Conference of Catholic Bishops and Evangelical Lutheran Church in America, Declaration on the Way: Church, Ministry, and Eucharist (2015), http://www.usccb.org/beliefs-and-teachings/ecumenical-andinterreligious/ecumenical/lutheran/upload/Declaration on the Way-for-Website.pdf.

24. Roman Catholic/Lutheran Joint Commission, The Ministry in the Church (1981), 82, http://www.prounione.urbe.it/dia-int/l-rc/doc/e I-rc ministry.html.

25. Evangelical Lutheran Church in America, "Full Communion Partners," http://www.elca.org/Faith/Ecumenicaland-Inter-Religious-Relations/Full-Communion.

26. Notably, Franklin Clark Fry (1900-1968), a Lutheran minister of the United Lutheran Church in America was known for his work on interdenominational unity and a moving force in the formation of the Lutheran World Federation (1947), the World Council of Churches (1948), and the National Council of Churches (1950). He also engineered the merger of the United Church in America, the Finnish Evangelical Lutheran Church of America, the American Evangelical Lutheran Church, and the Augustana Evangelical Lutheran Church to form the Lutheran Church in America (LCA) in 1962. See Robert H. Fischer, "Franklin Clark Fry: A Palette for a Portrait," supplement, Lutheran Quarterly 24 (1972).

27. Evangelical Lutheran Church in America, The Vision of the Evangelical Lutheran Church in America (1989), http://download.elca.org/ELCA\%20Resource\%20Repository/The Vision Of The ELCA. pdf. Chapter 4 of the constitution, "Statement of Purpose," declares that the Evangelical Lutheran Church in America is committed both to Lutheran unity and to Christian unity (4.03.d. and 4.03.f.).

28. Called to Common

Mission (1999), http://download.elca.org/ELCA\%20Resource\%20Repository/Called To Common Missio n.pdf. See also the collection of essays about the concordat by Lutheran and Episcopal theologians, Ephraim Radner and R. R. Reno, eds., Inhabiting Unity: Theological Perspectives on the Proposed Lutheran-Episcopal Concordat(Grand Rapids: Eerdmans, 1995).

29. Council for Christian Unity of the General Synod of the Church of England, The Porvoo Common Statement(1992), http://www.porvoocommunion.org/porvoo communion/statement/the-statementin-english/.

30. See examples of remaining differences in Declaration on the Way, 73-119. 
31. See Pieter de Witte, Doctrine, Dynamic and Difference: To the Heart of the Lutheran-Roman Catholic Differentiated Consensus on Justification, Ecclesiological Investigations 15 (New York: Bloomsbury T \& T Clark, 2012).

32. Joint Declaration on the Doctrine of Justification, 40.

33. See also David M. Chapman, "Consensus and Difference: The Elusive Nature of Ecumenical Agreement," Ecclesiology 8 (2012): 54-70, https://doi.org/10.1163/174553112x619726; Catherine Clifford, "The Joint Declaration, Method, and the Hermeneutics of Ecumenical Consensus," Journal of Ecumenical Studies 38, no. 1 (2001): 79-94; Minna Hietamäki, Agreeable Agreement: An Examination of the Quest for Consensus in Ecumenical Dialogue, Ecclesiological Investigations 8 (New York: T \& T Clark, 2010); Walter Kasper, That They May All Be One (New York: Burns \& Oates, 2004), 138; Harding Meyer, "Ecumenical Consensus," Gregorianum 77, no. 2 (1996): 213-25, and "Consensus in the Doctrine of Justification," Ecumenical Trends(December 1997): 165-68; Jakob Karl Rinderknecht, Mapping the Differentiated Consensus of the Joint Declaration (Cham, Switzerland: Palgrave Macmillan, 2016).

34. De Witte, Doctrine, Dynamic and Difference, 5.

35. Paul D. Murray, ed., Receptive Ecumenism and the Call to Catholic Learning: Exploring a Way for Contemporary Ecumenism (New York: Oxford University, 2008).

36. Ibid., ix-x.

37. John Paul II, Ut Unum Sint (May 25, 1995), 28, http://w2.vatican.va/content/iohn-paulii/en/encyclicals/documents/hf ip-ii enc 25051995 ut-unum-sint.html. See also Margaret O'Gara, The Ecumenical Gift Exchange (Collegeville, MN: Liturgical, 1998).

38. See Durham University Centre for Catholic Studies, "Receptive Ecumenism: Projects," https://www.dur.ac.uk/theology.religion/ccs/projects/receptiveecumenism/projects/.

39. See Francis, Evangelii Gaudium (November 24, 2013), 165, http://w2.vatican.va/content/francesco/en/apost exhortations/documents/papafrancesco esortazione-ap 20131124 evangelii-gaudium.html (hereafter cited as EG).

40. Jerome, Commentary on Titus 1:5 (Migne, PL 26.597).

41. Otto Hermann Pesch, "Existential and Sapiential Theology: The Theological Confrontation between Luther and Thomas Aquinas," in Catholic Scholars Dialogue with Luther, ed. Jared Wicks (Chicago: Loyola University, 1970), 61-81 and 182-93.

42. Pesch, "Existential and Sapiential Theology," 76.

43. Ibid., 79.

44. Ibid.

45. Ibid.

46. For an account of the merger that resulted in the ELCA, see Edgar Trexlar, Anatomy of a Merger: People, Dynamics, and Decisions that Shaped the ELCA (Minneapolis: Augsburg, 1991).

47. This division followed a major split at the seminary in St. Louis in 1974, which resulted in the formation of "Seminex" (Seminary in Exile).

48. Homepage, The Lutheran Church-Missouri Synod, http://www.Icmc.net.

49. North American Lutheran Church, "History," http://thenalc.org/history.

50. Mark Granquist, Lutherans in America: A New History (Minneapolis: Fortress, 2015), 348.

51. For an example, see A Brief Statement of the Doctrinal Position of the Missouri Synod (adopted 1932) and its section on creation: "We teach that God has created heaven and earth, and that in the manner and in the space of time recorded in the Holy Scriptures, especially Gen. 1 and 2, namely, by His almighty creative word, and in six days. We reject every doctrine which denies or limits the work of creation as taught in Scripture. In our days it is denied or limited by those who assert, ostensibly in deference to science, that the world came into existence through a process of evolution; that is, that it has, in immense periods of time, developed more or less of itself. Since no man was present when it pleased 
God to create the world, we must look for a reliable account of creation to God's own record, found in God's own book, the Bible." See "Of Creation," The Lutheran Church-Missouri Synod, http://www.Icms.org/doctrine/doctrinalposition\#creation.

52. Granquist, Lutherans in America, 246.

53. "The Bible FAQs," The Lutheran Church-Missouri Synod, http://www.Icms.org/faqs/lcmsviews\#bible.

54. "This We Believe: God and His Revelation," Wisconsin Evangelical Lutheran Synod, https://wels.net/aboutwels/what-we-believe/this-we-believe/gods-revelation/.

55. With the election of Gene Robinson, a priest in a non-celibate same-sex partnership, as bishop of New Hampshire in 2003, significant rifts began to appear, culminating in the action of the Primates' Gathering at Canterbury in January 2016, which imposed the penalty of suspension from ecumenical dialogues and voting in matters of doctrine and polity within the Communion for a period of three years for the Episcopal Church's action in its 2015 General Assembly to change its canonical definition of marriage to be gender neutral.

Fragmentation within the Anglican communion occurred when several African provinces broke communion with the Episcopal Church, some setting up parallel jurisdictions within the United States and Canada, such as the Anglican Mission in the Americas (AMiA), under Rwandan jurisdiction and formed in 2000 before the Robinson election, and the Convocation of Anglicans in North American (CANA), under Nigerian jurisdiction, formed in 2005.

The Global Anglican Future Conference (GAFCON), formed in 2008, sponsored the formation of a new province, the Anglican Church in North America (ACNA), comprised mainly of disaffected conservatives from the Episcopal Church and the Anglican Church of Canada. It also brought together disparate groups who had, for various reasons left the Episcopal Church, such as the Reformed Episcopal Church. Though the GAFCON provinces recognize and are in full communion with the ACNA, ACNA is not in communion with the See of Canterbury, and so is not a member province of the Anglican Communion.

AMiA left the ACNA less than a year after its formation and then experienced further fragmentation when, in 2011, the majority of AMiA bishops repudiated their Rwandan oversight and forged ahead autonomously. The remaining bishops under Rwandan oversight formed PEARUSA (an abbreviation of Province de l'Église Anglicane au Rwanda). In 2016, the parishes and dioceses of PEARUSA were transferred from Rwandan oversight and entered into full partnership with the ACNA.

56. Lutheran-Roman Catholic Commission on Unity, From Conflict to Communion: Lutheran-Catholic Common Commemoration of the Reformation in 2017 (Paderborn: Bonifatius, 2013).

57. "What Happened in the Reformation?" Evangelical Lutheran Church in America, http://www.elca500.org/the-observance.

58. Three German-language synods merged to form the ULCA: the General Synod (founded in 1820), the General Council (1867), and the United Synod of the South (1863). They were later joined by the Slovak Zion Synod (1919) in 1920 and by the Icelandic Synod (1885) in 1942. After a five-year merger process, the UCLA became part of the New Lutheran Church in America (LCA) in 1962.

59. See The Lutheran World Federation and the Pontifical Council for Promoting Christian Unity, The Apostolicity of the Church: Study Document of the Lutheran-Roman Catholic Commission on Unity (2006), 14964, http://www.prounione.urbe.it/dia-int/l-rc/doc/e I-rc ap-01.html; John J. Burkhard, Apostolicity Then and Now: An Ecumenical Church in a Postmodern World (Collegeville: Liturgical, 2004).

60. See Declaration on the Way, 92: "A correlation of ecumenical progress made on the church with issues of ministry is an especially urgent task, since such a correlation could support a qualified but immediate mutual recognition of ministry in such a way that a partial recognition of ministry would correlate with the real but imperfect communion of churches." 
61. See Richard Gaillardetz, "Vatican II and the Humility of the Church," in An Unfinished Council: Vatican II, Pope Francis, and the Renewal of Catholicism (Collegeville: Liturgical, 2015), 73-89. The Joint Working Group document, Reception: A Key to Ecumenical Progress, also speaks of the need for humility in section 15.

62. For the ecumenical application of the hierarchy of truths see Unitatis Redintegratio 11 and The Joint Working Group between the World Council of Churches and the Catholic Church, The Notion of the "Hierarchy of Truths": An Ecumenical Interpretation (1990), http://www.prounione.urbe.it/dia-int/jwg/doc/e jwgn6 7.html.

63. Gaudium et Spes (December 7, 1965),

92, http://www.vatican.va/archive/hist councils/ii vatican council/documents/vatii const 19651207 gaudium-et-spes en.html. 